\title{
THE ROLE OF CURRENCY HEDGING ON FIRM PERFORMANCE: A PANEL DATA EVIDENCE IN INDONESIA
}

\author{
Fiskara Indawan \\ Sri Fitriani \\ Indriani Karlina \\ Melva Viva Grace ${ }^{1}$
}

\begin{abstract}
This paper analyzes the role of currency hedging on non-financial firm's performance. Most firms on the sample have anticipated the currency mismatch risk by balancing the ratio of foreign debt to their asset denominated in foreign currency. Using panel estimation, we find that there is no evidence of currency hedging activities to affect capital and performance of firms. The result underlines the low intensity of currency hedging activities due to lack of incentives, which is inline with the low derivative transaction within the underdeveloped foreign currency market. This finding may raise a concern since currently the development of foreign liabilities for non-financial firmsin Indonesia is increasing in significant level, as well as the increase risk of domestic currency depreciation. For these reasons, Bank Indonesia should take proactive policies to deepen foreign currency market as well as derivative market by providing a more comprehensive and market friendly hedging instruments to banks and non-financial firms, while keep promoting the benefit of currency hedging.
\end{abstract}

Keywords: Hedging, derivative market, foreign liability.

JEL Classification: F31, G31

1 Researcher on Economic Research Bureau, Department of Economic and Monetary Policy Research, Bank Indonesia. The views on this paper are solely of the authors and do not represent the views of Bank Indonesia. Authors thanks to Dr. Iskandar Simorangkir and Dr. Noer Azam for constructive input and discussion. E-mail: indawan@bi.go.id (corresponding author),sfitriani@bi.go.id, indriani_k@bi.go.id, melva_vg@bi.go.id. 


\section{PENDAHULUAN}

Di tengah kondisi perekonomian global yang masih belum menunjukkan kepastian seperti saat ini, perkembangan total utang luar negeri yang terus meningkat sejak tahun 2006 dapat memberikan dampak yang tidak menguntungkan (upside risk) terhadap perekonomian. Pada akhir September 2012, posisi total utang luar negeri tercatat sebesar 243,9 miliar USD. Dari total ULN, perusahaan non keuangan mengusai pangsa 35\% atau USD85 miliar (rata-rata periode Maret 2003- September 2012) (Grafik 1). Jumlah utang luar negeri yang sangat besar khususnya yang dimiliki sektor perusahaan non keuangan tersebut berpotensi memiliki risiko ketidaksesuaian nilai tukar (currency mismatch) sebagai akibat dari fluktuasi pergerakan nilai tukar khususnya pengaruh dari depresiasi nilai tukar.

Di sisi lain, nilai tukar Rupiah terhadap USD menunjukkan perkembangan yang sangat berfluktuatif sebagai akibat dari perkembangan dalam negeri maupun eksternal (Grafik 2). Nilai tukar mengalami depresiasi yang tajam dalam beberapa periode seperti pada tahun 1997 dimana terjadi krisis keuangan Asia sebagai dampak contagion effect dari krisis di Thailand dan kehilangan kepercayaan investor asing terhadap perekonomian domestik. Pada tahun 2005 terjadi mini crisis sebagai dampak dari lonjakan inflasi yang mencapai $17 \%$ sebagai akibat peningkatan harga BBM, dan terakhir di akhir tahun 2008 yang terjadi krisis keuangan global. Ke depan, kondisi perekonomian global yang masih menunjukkan ketidakpastian berpotensi untuk dapat meningkatkan fluktuasi khususnya depresiasi nilai tukar.



Grafik 1.

Perkembangan ULN Total dan Perusahaan Non Keuangan

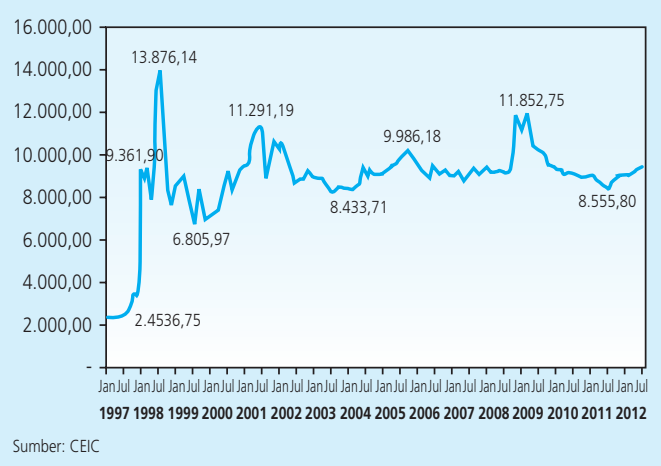

Grafik 2.

Perkembangan Nilai Tukar Rupiah terhadap USD

Bagi perusahaan, pembiayaan melalui (ULN) dapat diibaratkan sebagai pedang bermata dua. Di satu sisi, ULN menyediakan pembiayaan bagi perusahaan baik untuk kegiatan produksi maupun ekspansi usaha. Namun disisi lain, tingginya ULN akan mengakibatkan perusahaan 
terekspos pada risiko ketidaksesuaian nilai tukar (currency mismatch risk). Secara teoritis, depresiasi nilai tukar memiliki dua pengaruh terhadap perekonomian khususnya bila ditinjau dari kondisi perusahaan yaitu balance-sheet effect dan competitiveness effect. Balance-sheet effect terjadi apabila beban utang valas akan semakin besar dan kemudian akan mengurangi modal (net worth) perusahaan sehingga pada akhirnya akan mengurangi kemampuan investasi perusahaan dan output. Sedangkan competitiveness effect terjadi apabila depresiasi nilai tukar akan menyebabkan murahnya harga barang ekspor dalam negeri sehingga meningkatkan volume ekspor produk perusahaan dan ouput domestik.

Krisis ekonomi dan moneter di tahun 1997 memberikan pengalaman akibat dari dampak buruk depresiasi nilai tukar yang tajam yang mengakibatkan melonjaknya beban angsuran maupun pembayaran pokok ULN perusahaan. Hal ini pada akhirnya membuat perusahaan mengalami kesulitan pembayaran ULN dan menjadi default mengingat sebagian besar pendapatan diperoleh dalam mata uang domestik. Untuk mengantisipasi potensi risiko nilai tukar (currency mismatch) sebagai akibat tajamnya depresiasi nilai tukar, perusahaaan dituntut untuk melakukan lindung nilai (hedging) terhadap ULN agar dapat melindungi kondisi keuangannya dari kebangkrutan. Salah satu cara lindung nilai yang dapat dilakukan perusahaan adalah menggunakan transaksi derivatif yang terdiri dari transaksi forward, swap dan option (currency hedging).

Namun, dalam perkembangannya volume transaksi derivatif di pasar valas Indonesia masih terbatas khususnya bila dibandingkan dengan negara-negara kawasan (Grafik 3). Hal ini berdampak pada terbatasnya perkembangan transaksi derivatif yang merupakan bagian dari transaksi di pasar valas domestik (Grafik 3). Selama periode 2005 - 2011, sebagian besar transaksi valas dilakukan dalam bentuk TTS (Today, Tomorrow, dan Spot) atau 68\% dari volume



Grafik 3.

Volume Harian Transaksi Valas di Kawasan ASEAN

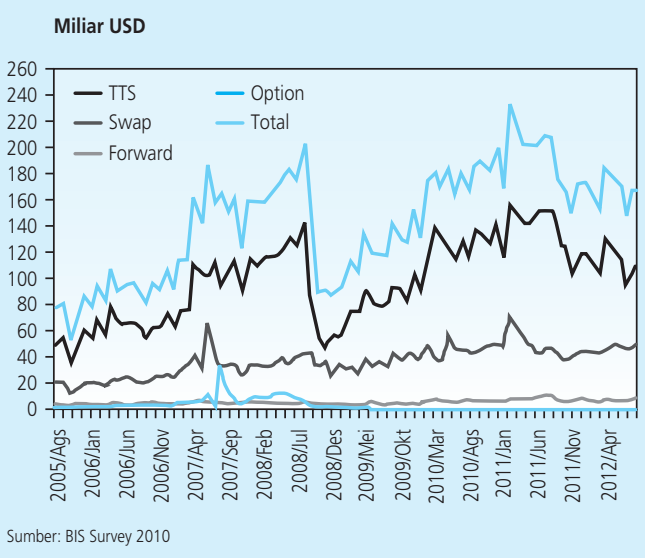

Grafik 4.

Perkembangan Instrumen Pasar Valas (Total Volume) 
total transaksi, sedang sisanya berupa transaksi derivatif dalam bentuk swap, forward, dan option selain itu peranan perusahaan non keuangan di pasar valas dan pasar derivatif juga belum menunjukkan perkembangan yang memuaskan.

Pelaku pasar terbesar di pasar valas dan pasar derivatif di Indonesia masih didominasi oleh perbankan domestik yang menguasai hampir 64\% dari total transaksi di pasar valas dan $70 \%$ di pasar derivatif (Grafik 5 dan 6). Sementara peranan perusahaan non keuangan hanya memiliki peranan sekitar $12 \%$ di pasar valas dan $7 \%$ di pasar derivatif.

Apabila ditinjau berdasarkan tiga jenis instrumen yang ada di pasar derivatif domestik, maka instrumen pertama yakni swap, merupakan instrumen terbesar di pasar derivatif yang didominasi oleh pelaku perbankan (74\%), diikuti oleh pihak LN $(22,7)$, perusahaan $(2,8 \%)$ dan individu (0,27\%) (Tabel 4 dan Grafik 5). Untuk instrument kedua, forward (Tabel 4 dan Grafik $6)$, juga didominasi oleh perbankan (51,84\%) kemudian diikuti oleh perusahaan $(31,42 \%)$. Untuk instrumen ketiga, pasar option (Tabel 4 dan Grafik 7), transaksi volumenya sangat kecil hanya USD389,8 juta menunjukan bahwa peran pelaku pangsa individu (14,5\%) lebih besar daripada pelaku perusahaan (9,3\%).



Grafik 5.

Pangsa Pelaku Transaksi Swap (\%)

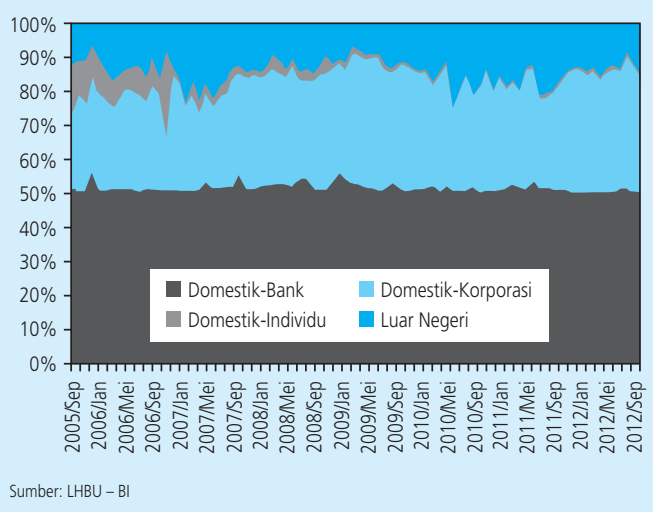

Grafik 6.

Pangsa Pelaku Transaksi Forward (\%) 




Fakta bahwa volume transaksi untuk instrumen swap dan forward yang terus meningkat (Grafik 8 dan 9), sementara transaksi option cenderung menurun tajam sejak Juni 2009 (Grafik 10), merupakan indikasi positifnya ekspektasi pelaku pasar terhadap kondisi perekonomian. Logika ini jelas mengingat instrumen option tergolong instrumen yang bersifat asuransi.

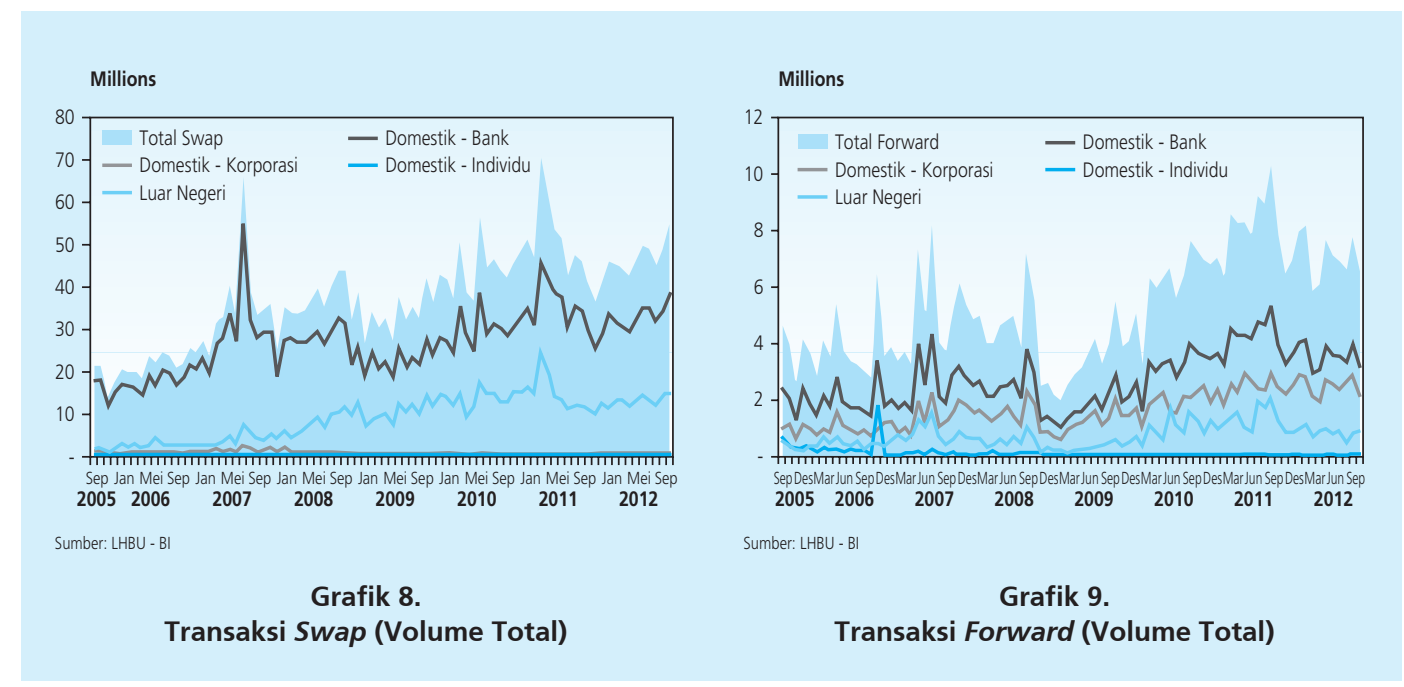




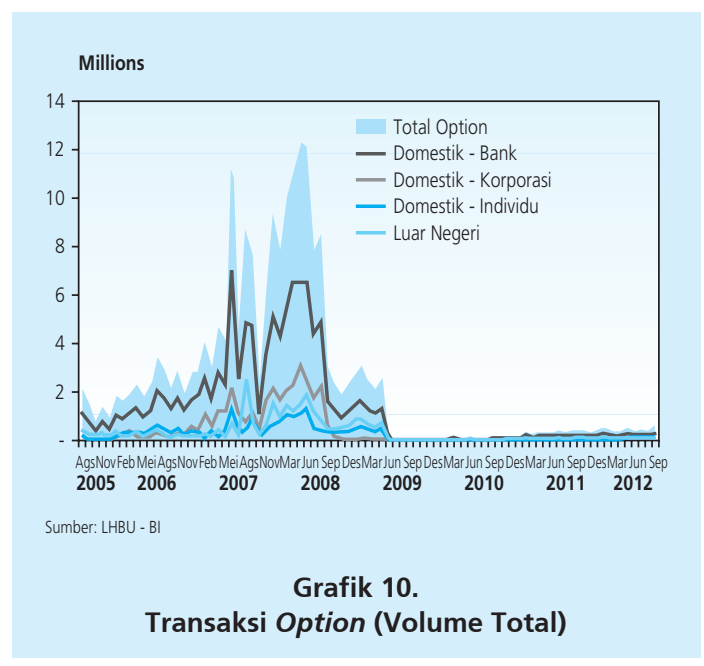

Terlepas dari indikasi positifnya ekspektasi pelaku pasar tersebut, namun dalam kenyataan, trend yang terjadi menunjukkan bahwa nilai Rupiah cenderung mengalami depresiasi hingga awal tahun 2015 ini (Grafik 11). Kedepan, masih rapuhnya proses pemulihan, tingginya ketidakpastian perekonomian global, dan risiko ketidakseimbangan neraca pembayaran dapat berpotensi meningkatkan pembalikan aliran modal sewaktu-waktu yang meningkatkan kerentanan resiko depresiasi lebih lanjut Rupiah. Dengan pertimbangan hal tersebut, perusahaan yang memiliki ULN sangat membutuhkan transaksi hedging (lindung nilai) agar dapat mengelola resiko nilai tukar serta menjaga kondisi perusahaannya.

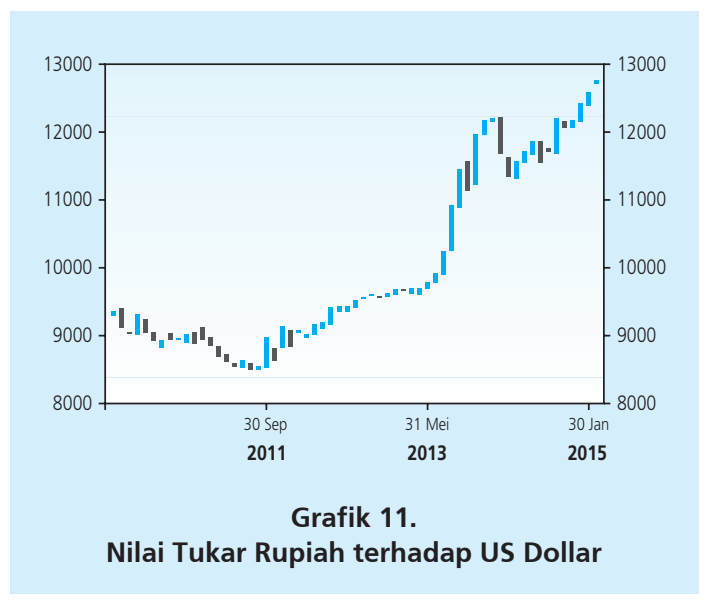

Paper ini akan meneliti lebih jauh mengenai peranan currency hedging perusahaan dalam manajemen risiko nilai tukar. Secara eksplisit, tujuan dari paper ini adalah untuk menganalisis pengaruh aktivitas hedging terhadap kinerja perusahaan. Bagian kedua dari paper ini akan 
menguraikan teori dan studi empiris yang terkait dengan pokok bahasan. Bagian ketiga menyajikan data dan metodologi yang digunakan, sementara bagian keempat mengulas hasil dan pembahasan. Kesimpulan akan diberikan pada bagian kelima dan menjadi penutup dari paper ini.

\section{TEORI}

Pengaruh fluktuasi nilai tukar terhadap kondisi keuangan perusahaan yang memiliki utang valas dapat dijelaskan melalui konsep balance-sheet effect. Beberapa literatur telah menjelaskan konsep balance sheet effect seperti pada Krugman (1999), Cespedes (2000) dan Aghion (2001 dan 2003). Secara umum, konsep tersebut menjelaskan bahwa fluktuasi nilai tukar akan berpengaruh pada kemampuan perusahaan dalam ekspansi maupun berproduksi. Melalui pendekatan balance-sheet effect ini dapat dijelaskan dampak depresiasi nilai tukar terhadap resesi perekonomian. Beban utang valas yang akan melonjak cepat akibat depresiasi akan mengurangi modal perusahaan (net worth) sehingga pada akhirnya akan mengurangi kemampuan berproduksi dan berinvestasi perusahaan. Banyaknya perusahaan yang bangkrut sebagaimana dialami pada krisis keuangan Asia 1997 mendorong perekonomian domestik jatuh pada resesi.

Secara khusus menurut Aghion et al (2001), interaksi antara fluktuasi nilai tukar dengan output perusahaan dapat dijelaskan dari sisi wealth entrepreneur. Perusahaan akan mengandalkan modal dari entrepreneur sebagai input dalam proses produksi sehingga diperoleh:

$$
y_{t}=f\left(w_{t}\right)
$$

Selanjutnya untuk menambah wealth yang dibutuhkan untuk proses produksi pada periode selanjutnya, entrepreneur meminjam dana dari dalam negeri $d_{t}^{c}$ dan luar negeri $d_{t}^{t}$ dengan membayar bunga masing-masing sebesar $i_{t}$ dan $i{ }_{t}{ }_{t}$ serta dengan nilai tukar nominal $E_{t}$. Dengan demikian diperoleh fungsi persamaan profit entrepreneur sebagai berikut:

$$
\pi_{t}=P_{t} y_{t}-\left(1+i_{t}\right) P_{t} d_{t}^{c}-\left(1+i_{t}^{*}\right) \frac{E_{t}}{E_{t-1}} P_{t} d_{t}^{f}
$$

Entrepreneur selanjutnya akan menggunakan profit yang diperoleh pada periode saat ini sebagai wealth yang pada periode berikutnya sehingga menjadi:

$$
w_{t+1}=f\left(\frac{\pi_{t}}{P_{t}}\right)
$$

Wealth tersebut akan digunakan sebagai input dalam produksi pada periode berikutnya sehingga diperoleh 


$$
y_{t+1}=f\left\{y_{t}-\left(1+r_{t}\right) d_{t}^{c}-\left(1+i_{t}^{*}\right) \frac{E_{t}}{P_{t}} d_{t}^{f}\right\}
$$

$r_{t}$ adalah suku bunga riil yang didefinisikan sebagai $1+r_{t}=\left(1+i_{t}\right) P_{t} / P_{t+1}$.

Berdasarkan persamaan (4) diperoleh bahwa output yang dihasilkan perusahaan akan turun bila terjadi kenaikan biaya utang luar negeri yang disebabkan dari adanya depresiasi nilai tukar. Perusahaan yang melakukan utang luar negeri akan mengalami penurunan modal apabila terjadi depresiasi nilai tukar. Untuk dapat mempertahankan kondisi keuangan melalui jalur wealth, perusahaan dituntut untuk melakukan lindung nilai (hedging) terhadap utang luar negeri miliknya, atau dengan kata lain perusahaan akan berupaya untuk melakukan currency matching apabila menerima utang luar negeri dengan tujuan untuk menjaga keseimbangan/ kesetaraan kondisi neraca keuangannya.

Perusahaan yang memiliki ULN dapat melakukan beberapa cara agar dapat mengelola risiko nilai tukarnya sebagai berikut (Bodie and Merton, 2000): pertama, menghindari risiko dengan tidak melakukan transaksi yang dapat berdampak pada risiko nilai tukar; kedua, mengurangi risiko kerugian dengan misalnya pemilihan lokasi produksi, terutama bagi perusahaan multinasional; ketiga, mentransfer risiko kepada pihak lain melalui lindung nilai dengan menggunakan, instrumen derivatif, asuransi, dan diversifikasi risiko dengan menggunakan beberapa supplier yang berbeda: dan keempat, menahan risiko (tidak berbuat apa-apa) selama risiko masih pada level yang rasional.

Berbagai penelitian telah banyak dilakukan untuk mengetahui peranan currency matching dan currency hedging bagi perushaan dalam rangka manajemen risiko nilai tukar di beberapa negara. Secara umum, penelitian tersebut menemukan hasil yang signifikan mengenai peranan currency matching dan currency hedging dalam manajemen risiko nilai tukar, khususnya risiko currency mismatch. Kamil, et. al (2009) menggunakan 1200 sampel perusahaan publik di Amerika Latin dan menemukan bahwa dalam satu dekade terakhir, perusahaan telah mengurangi kerentanan terhadap risiko nilai tukar dengan mengurangi currency mismatch pada neraca. Hal ini dilakukan dengan mengurangi ketergantungan pada utang valas dan kemudian pencocokan kewajiban dalam valas dengan aset atau dengan ekspektasi aliran valas. Sementara, Cowan, et.al, (2005) melakukan studi pada perusahaan non-keuangan di Chili dengan menggunakan data panel. Hasil empiris yang ditemukan dalam studi tersebut diantaranya adalah: (1) Perusahaan melakukan currency matching antara hutang valas dengan aset maupun pendapatan, (2) Perusahaan secara aktif melakukan hedging terhadap eksposur neraca (balance sheet effect), (3) Penggunaan derivatif berperan dalam melindungi investasi perusahaan dari guncangan nilai tukar.

Studi empiris mengenai manajemen risiko nilai tukar juga dilakukan Sahminan (2006) di Indonesia dengan menggunakan data level industri sektor non-keuangan yang terdaftar di Bursa Efek Indonesia (BEI) yang mencakup sektor pertanian, pertambangan, barang konsumsi, industri dasar dan industri pengolahan. Selain itu juga dilakukan survei anekdotal dan ditemukan 
bahwa strategi hedging perusahaan bervariasi di seluruh perusahaan, beberapa perusahaan melakukan aktivitas hedging, sementara yang lain tidak. Instrumen hedging yang digunakan diantaranya: forward, swap, dan option. Alasan utama perusahaan yang tidak melakukan hedging adalah karena biaya hedging lebih besar dari manfaatnya.

Lebih lanjut, studi mengenai penggunaan hutang valas sebagai instrumen hedging dilakukan oleh Kedia dan Mozumdar (2003) dengan menggunakan probit. Terdapat pembuktian yang kuat bahwa motif perusahaan meminjam hutang valas adalah hedging, yaitu untuk melindungi perusahaan dari eksposur nilai tukar di tingkat agregat maupun individu perusahaan. Sedangkan penggunaan instrumen derivatif untuk manajemen nilai tukar diteliti oleh Borsum dan Odegaard (2004) pada perusahaan non keuangan di Norwegia. Dengan menggunakan metode survei, ditemukan bahwa: (1) Derivatif merupakan instrumen yang umumnya digunakan untuk manajemen risiko nilai tukar di perusahaan non-keuangan cukup tinggi, (2) Penggunaan derivatif sebagian besar masih diarahkan pada jangka pendek, (3) Alasan perusahaan yang tidak melakukan hedging diantaranya adalah: natural hedging, biaya lebih besar dibanding manfaatnya.

Studi lain dilakukan di Asia Timur (Allayanis, et.al, 2001) yang menganalisis mengenai manajemen nilai tukar pada level perusahaan. Hasil empiris menunjukkan bahwa perusahaan menggunakan pendapatan valas sebagai subtitusi hedging dan secara selektif menggunakan instrumen derivatif. Pada perusahaan tersebut, tidak terdapat perbedaan kinerja baik bagi perusahaan yang menggunakan derivatif maupun tidak pada saat sebelum krisis dan selama krisis. Namun pasca krisis, perusahaan yang menggunakan derivatif memiliki kinerja lebih baik.

Pada sisi lain, kedalaman pasar derivatif merupakan faktor lain yang essensial dalam pengembangan pasar valas terutama bagi negara yang menerapkan kebijakan nilai tukar mengambang (floating exchange rate) seperti Indonesia. Transaksi valas adalah transaksi yang didasari oleh suatu kontrak jual beli antara mata uang dengan mata uang lainnya. Transaksi valas dapat berfungsi (1) sebagai lindung nilai (hedging) yaitu mentransfer risiko pemegang underlying kepada counterparty atau (2) sebagai spekulasi yaitu mencari keuntungan yang biasanya dilakukan tanpa underlying. Jenis transaksi valas terdiri dari: transaksi TOD (Today), TOM (Tomorrow), SPOT serta transaksi derivatif. Transaksi derivatif adalah transaksi yang didasari oleh suatu kontrak atau perjanjian yang nilainya merupakan turunan dari nilai instrumen yang mendasari seperti suku bunga, nilai tukar, komoditas, ekuitas dan indeks, baik yang diikuti dengan pergerakan atau tanpa pergerakan dana atau instrumen. Instrumen transaksi derivatif valas diantaranya adalah forward, option, swap, dan futures.

Pasar derivatif valas yang berkembang dan dalam diharapkan dapat berkontribusi bagi tersedianya berbagai instrumen pilihan transaksi dalam pengelolaan risiko nilai tukar (currency risk management) baik bagi perusahaan maupun rumah tangga. Ketersediaan berbagai instrumen lindung nilai tersebut diharapkan dapat membantu menyeimbangkan permintaan dan penawaran di pasar valas, sehingga dapat mengurangi volatilitas nilai tukar. 
Pengalaman di negara emerging market menunjukkan bukti yang mixed mengenai hubungan antara aktivitas perdagangan derivatif di pasar valas dengan volatilitas nilai tukar. Penelitian yang dilakukan oleh Bank Sentral India menunjukkan bahwa terdapat hubungan sebab akibat dua arah antara volatilitas nilai tukar (spot) dengan aktivitas perdagangan transaksi derivatif dalam bentuk futures di pasar valas (Sharma, 2011). Hal serupa juga ditemukan pada studi yang dilakukan oleh Chen, et.al (2011) mengenai perilaku investor dalam pasar futures di Korea Selatan. Hasil studi mengindikasikan adanya hubungan positif yang signifikan antara volatilitas nilai tukar Won/USD dan volume transaksi futures yang dilakukan baik oleh bank maupun pelaku asing. Sedangkan hubungan kausalitas satu arah terjadi antara volume transaksi baik yang dilakukan oleh perbankan maupun pelaku asing terhadap volatilitas nilai tukar di pasar futures Korea Selatan.

Dalam Sharma, 2011,Chatrath, Ramchander dan Song (1995) menunjukkan bukti hubungan satu arah yang kuat antara, aktivitas perdagangan future di pasar valas dengan volatilitas nilai tukar spot rate British pound, Canadian dollar, Japanese yen, Swiss franc and Deutsche mark. Sementara itu, Adrangi dan chatrath (1998) dalam Sharma (2011) menyimpulkan bahwa pertumbuhan komitmen currency futures tidak mengakibatkan peningkatan volatilitas nilai tukar, tetapi peningkatan spekulasi dalam jumlah besar dan terbatasnya pedagang/hedger berdampak pada ketidakstabilan di pasar valas.

\section{METODOLOGI}

\subsection{Model Empiris}

Untuk mengetahui efektifitas transaksi hedging dilakukan pengujian dampak volume transaksi hedging terhadap net wealth perusahaan dan kinerja perusahaan. Pengujian tersebut dilakukan dengan menggunakan dua pendekatan; pertama dari sisi neraca perusahaan (balancesheet effect) mengikuti model empiris Kurniati dkk. (2007) dan ukuran kinerja perusahaan mengikuti model empiris Allayanis dkk. (2001).

Pada pendekatan pertama, kami menyesuaikan variabel control dari model empiris yang telah digunakan oleh Kurniati dkk. (2007). Dalam model ini, net worth perusahaan di proksi dengan modal perusahaan. Model ini diturunkan dari neraca perusahaan yang disederhanakan, sehingga diperoleh reduced form sebagai berikut:

$$
\begin{aligned}
\mathrm{EQ}_{\mathrm{i}, \mathrm{t}}=\alpha_{0}+ & \alpha_{1}\left[\left(A_{f}-L_{f}\right)_{i, t-1} \cdot \Delta e_{t}\right]+\alpha_{2}\left(A_{f}-L_{f}\right)_{i, t-1} \\
& +\alpha_{3} \Delta e_{t}+\alpha_{4} L_{i, t-1}^{d}+\alpha_{5} r c_{t}+\alpha_{5} D E R T_{i, t}
\end{aligned}
$$

Apabila $\left(A_{f}-L_{f}\right)=N F A$ maka:

$$
\begin{aligned}
\mathrm{EQ}_{\mathrm{it}}= & \alpha_{0}+\alpha_{1}\left[(N F A)_{i, t-1} \cdot \Delta e_{t}\right]+\alpha_{2}(N F A)_{i, t-1} \\
& +\alpha_{3} \Delta e_{t}+\alpha_{4} L_{i, t-1}^{d}+\alpha_{5} r c_{t}
\end{aligned}
$$


Dalam hal ini, $\mathrm{EQ}_{i, t}$ adalah net worth perusahaan; $\left(\mathrm{A}_{\mathrm{f}}-\mathrm{L}_{\mathrm{f}}\right)$ adalah net foreign asset (foreign asset - foreign liabilities); $\mathrm{e}_{\mathrm{t}}$ adalah nilai tukar; $\mathrm{r}_{\mathrm{t}}$ adalah suku bunga working capital; $\mathrm{L}_{\mathrm{i}, \mathrm{t}-\mathrm{i}}$ adalah utang domestik; dan DERT adalah transaksi derivatif.

Variabel utama dalam model ini adalah $\left[(N F A)_{i, t-1} . \Delta e_{t}\right]$ yaitu interaksi antara NFA (selisih antara aset valas dengan utang valas) dengan perubahan nilai tukar. Koefisien dari variabel ini menunjukkan efek mana yang lebih dominan: balance-sheet effect atau competitiveness effect. Koefisien positif mengindikasikan efek peningkatan daya saing lebih dominan sementara koefisien yang negatif mengindikasikan efek deteriorate terhadap neraca perusahaan yang lebih dominan. Untuk menangkap efek NFA terlepas dari besarnya perubahan nilai tukar digunakan $(\mathrm{NFA})_{\mathrm{i}, \mathrm{t}-1}$, sedangkan variabel $\Delta \mathrm{e}_{\mathrm{t}}$ digunakan untuk melihat seberapa besar pengaruh perubahan nilai tukar terlepas dari besarnya NFA. Selanjutnya, variabel kontrol yang digunakan adalah utang dengan kurs domestik untuk mengukur tingkat leverage perusahaan, suku bunga modal kerja, dan volume transaksi derivatif yang dilakukan oleh perusahaan (DERT).

Selain efektifitas transaksi hedging terhadap net worth, juga dilakukan pengujian terhadap kinerja perusahaan seperti yang digunakan oleh Allayanis et al (2001) dengan spesifikasi sebagai berikut:

$$
Y_{i t}=\alpha_{0}+\alpha_{1} R D E R T_{i t}+\alpha_{2} R F R A S_{i t}+\alpha_{3} R F L I S_{i t}+\alpha_{3} R E X S_{i t}+\varepsilon_{i t}
$$

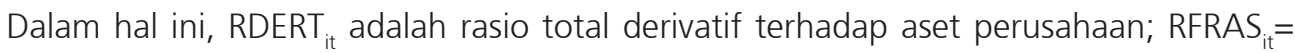
rasio foreign aset terhadap aset perusahaan; RFLIS $_{\text {it }}=$ rasio foreign liabilities terhadap aset perusahaan; dan $\mathrm{REXS}_{\mathrm{it}}=$ rasio export terhadap sales perusahaan

Volume transaksi hedging sebagai independen variabel. Sementara beberapa indikator kinerja perusahaan yang digunakan sebagai dependen variabel adalah seperti laba bersih, biaya pokok perusahaan (cost of goods sold). Indikator lainnya adalah pengujian dengan menggunakan market-to-book ratio dan EBIT seperti yang digunakan oleh Allayanis et al (2001).

\subsection{Data}

Data utama penelitian ini adalah data 128 perusahaan yang diperoleh dari laporan keuangan emiten tahunan yang dipublikasi dari Bursa Efek Indonesia selama periode 2005 2011. Data-data tersebut meliputi seperti total aset, liabilities, equity, foreign asset, dan foreign liabilities. Data lainnya secara detail dan sumbernya seperti transaksi valas, ekspor impor, ULN dan dan nilai tukar adalah sebagaimana Tabel 1.

Sebagaimana telah diungkapkan sebelumnya, transaksi derivatif dalam paper ini menggunakan data yang diperoleh dari Laporan Harian Bank Umum (LHBU). Dalam LHBU, volume transaksi derivatif merupakan bagian dari transaksi valas di pasar domestik dan terdiri dari 3 instrumen yaitu forward, option dan swap. Data volume transaksi derivatif untuk masingmasing transaksi dikelompokkan menjadi volume transaksi beli, jual, dan total. 


\begin{tabular}{l|c}
\multicolumn{1}{c}{$\begin{array}{c}\text { Tabel 1 } \\
\text { DATA dan Sumber Penelitian }\end{array}$} & $\begin{array}{c}\text { SUMBER } \\
\text { Neraca keuangan Perusahaan Publik } 120 \text { perusahaan, meliputi Foreign }\end{array}$ \\
Asset/Liabilities, Sales, Net Income, Utang domestik, COGS, operating expenses. & Lapkeu Perusahaan - BEI \\
\hline Transaksi Pasar Valas (Tod/Tom/Spot, Forward, Swap, dan Option) & LHBU (BI-DPM) \\
\hline Ekspor Impor Perusahaan & PEB (BI-DSM) \\
\hline Pinjaman LN Perusahaan & CEIC/DInt \\
\hline Ratio - ratio keuangan perusahaan (current ratio, market-to-book ratio, ebit, & \\
gross margin) & CEIC \\
\hline Nilai Tukar & BI-DInt \\
\hline Survei Manajemen Risiko &
\end{tabular}

\section{HASIL ESTIMASI DAN ANALISIS}

Hasil estimasi ini menunjukkan bahwa penggunaan instrumen derivatif belum terbukti berpengaruh secara signifikan terhadap net worth perusahaan (Tabel 2 dan Tabel 3). Namun, net worth perusahaan dipengaruhi secara signifikan dan negatif oleh interaksi antara foreign asset dengan nilai tukar dan lag nilai tukar. Sementara lag NFA dan lag DL (Domestic Liabities) mempengaruhi net worth secara signifikan dan positif. Temuan ini menunjukkan bahwa perusahaan masih rentan terhadap eksposure nilai tukar, walaupun perusahaan telah berupaya melakukan currency matching. Deskripsi berikut ini akan menunjukkan bahwa upaya yang telah dilakukan oleh perusahaan-perusahaan ini, belum sebanding dengan potensi currency mismatch yang mereka hadapi.

\begin{tabular}{l|c}
\multicolumn{2}{c}{ Tabel 2} \\
Hasil Uji Empiris Efektifitas Hedging terhadap \\
Net Worth Perusahaan (BS Effect) \\
Variabel Dependen & Rasio Ekuitas \\
Konstanta & -2.269 \\
\hline FA*Nilai Tukar & $-88.553^{* * *}$ \\
\hline NFA (-1) & $12.641^{* * *}$ \\
\hline Nilai Tukar (-1) & $-14.133^{* * *}$ \\
\hline Rasio Derivatif (-1) & -0.021 \\
\hline DL (-1) & $0.052^{* * *}$ \\
\hline R-Squared & 0.455 \\
\hline N & 756.000 \\
\hline Estimator & FE \\
\hline Hausman Test & 0.000 \\
\hline
\end{tabular}




\begin{tabular}{|c|c|c|c|}
\hline \multicolumn{4}{|c|}{$\begin{array}{c}\text { Tabel } 3 \\
\text { Hasil Uji Empiris Efektifitas Hedging terhadap Kinerja Perusahaan }\end{array}$} \\
\hline \multirow[t]{2}{*}{ Dependen Variabel } & Rasio Net Income & Rasio EBIT & $\begin{array}{l}\text { Rasio Operating } \\
\text { Expenditures }\end{array}$ \\
\hline & (1) & (2) & (3) \\
\hline Konstanta & $0.556^{\star * *}$ & $0.65^{\star * *}$ & $-0.679^{* * *}$ \\
\hline Rasio Transaksi Derivatif & 0 & 0 & 0 \\
\hline \multicolumn{4}{|l|}{ Rasio EBIT } \\
\hline Rasio Ekspor & -0.008 & 0.044 & 0.047 \\
\hline Rasio Foreign Asset & $-0.537^{\star \star \star}$ & $-0.763^{\star \star *}$ & $0.563^{\star * *}$ \\
\hline Rasio Foreign Liabilities & $0.995^{\star \star \star}$ & $1.125^{\star \star \star}$ & $-1.01^{* * *}$ \\
\hline Rasio Liabilities & $-1.312^{\star * *}$ & $-1.702^{* * *}$ & $2.214^{* * *}$ \\
\hline Rasio Sales & 0.039 & $0.109^{* * *}$ & $-0.131^{* * *}$ \\
\hline \multicolumn{4}{|l|}{ Changes GM } \\
\hline$R$ - squared & 0.3041 & 0.2043 & 0.144 \\
\hline $\mathrm{N}$ & 761 & 761 & 761 \\
\hline Estimator & FE & FE & $\mathrm{FE}$ \\
\hline Haussman Test & 0.000 & 0.000 & 0.000 \\
\hline
\end{tabular}

Hasil pengujian dengan dua pendekatan tersebut menunjukkan bahwa transaksi hedging masih belum mempengaruhi net worth (modal perusahaan) maupun kinerja perusahaan secara signifikan. Hal tersebut mengindikasikan bahwa belum terdapat dorongan yang kuat bagi perusahaan untuk melakukan currency hedging dalam rangka melindungi nilai kekayaan maupun kinerja perusahaan terhadap eksposur risiko nilai tukar. Selanjutnya pembahasan akan dilanjutkan untuk mengetahui mengapa perusahaan belum melakukan transaksi hedging untuk melindungi nilai kekayaan maupun kinerja perusahaan.

Meski perusahaan-perusahaan dalam sampel penelitian ini telah berusaha menyeimbangkan antara rasio foreign liability dengan rasio foreign asset, namun tetap berpotensi terekspos risiko currency mismatch (Grafik 12). Penurunan rasio foreign liability terjadi cukup pesat dari 53,2\% (2000) menjadi 22,6\% (2004). Namun demikian, kesenjangan antara rasio foreign liability dengan rasio foreign asset tampak masih relatif lebar. Pada 2011, rasio foreign liability sebesar $17 \%$ sedangkan rasio foreign asset sebesar 6,3\%. Masih relatif lebarnya kesenjangan tersebut menggambarkan bahwa perusahaan masih berpotensi menghadapi risiko currency mismatch. 




Sesuai dengan hasil estimasi yang menunjukkan tidak signifikannya pengaruh hedging terhadap net worth perusahaan, data di atas menunjukkan bahwa meskipun berpotensi mengalami risiko currency mismatch yang tinggi, tercatat hanya sebagian kecil dari sampel perusahaan yang melakukan transaksi lindung nilai melalui transaksi derivatif. Setelah mencapai puncaknya di 2008 yang mencapai 44 perusahaan atau 34\% dari total sampel, terjadi penurunan perusahaan yang melakukan transaksi hedging (Grafik 14 dan 15).

Pada tahun 2011 hanya 20 perusahaan yang melakukan transaksi derivatif (16\%). Tingginya perusahaan yang melakukan transaksi hedging di tahun 2008 adalah sebagai dampak dari krisis global yang menyebabkan terjadinya peningkatan ekspektasi risiko nilai tukar. Namun sejak pertengahan 2009, seiring dengan pulihnya kinerja ekonomi domestik dan kawasan

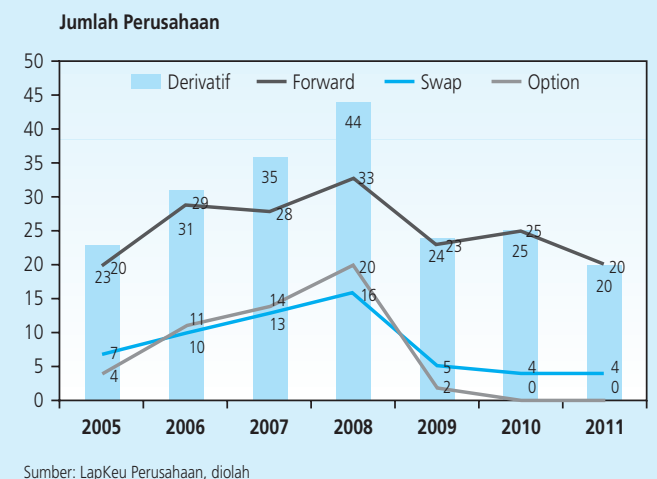

Grafik 14.

Jumlah Perusahaan yang Melakukan Hedging



Sumber: LapKeu Perusahaan, diolah

Grafik 15.

Persentase Perusahaan yang Melakukan Hedging terhadap Total Sampel 
Asia Pasifik dari dampak krisis global, ekspektasi risiko nilai tukar juga mengalami penurunan sehingga berpengaruh pula pada penurunan transaksi derivatif dari sampel perusahaan. Apabila ditinjau dari jenis instrumen, transaksi derivatif yang banyak digunakan adalah forward dan swap, sementara penggunaan transaksi option relatif kecil. Pada 2010 dan 2011 tidak ada perusahaan sampel yang menggunakan transaksi option.

Hal serupa juga terlihat dalam pengujian efektivitas hedging terhadap indikator kinerja perusahaan (lihat Tabel 11). Rasio transaksi derivatif secara empiris belum berpengaruh signifikan terhadap indikator kinerja perusahaan berupa rasio net income, rasio EBIT, dan rasio operating expenditures. Indikator kinerja perusahaan secara umum dipengaruhi secara signifikan oleh rasio foreign asset dan liabilities.

Berdasarkan laporan keuangan yang telah dipublikasi, pada 128 perusahaan nonkeuangan yang telah go public, terdapat tren peningkatan foreign liability dan foreign asset serta diikuti pula total asset (Grafik 16). Kecuali pada periode 2000-2004, perkembangan foreign liability perusahaan tetap tinggi, dan cenderung meningkat, yang mencapai Rp133 triliun pada 2011. Tren peningkatan juga dialami oleh foreign asset perusahaan yang mencapai Rp49,5 triliun pada 2011. Sejak 2004, secara nominal, total asset perusahaan terus meningkat dan Rp800 triliun di akhir tahun 2011.

Lebih jauh, kami berupaya menjelaskan ketidakmampuan transaksi hedging yang dilakukan perusahaan dalam mempengaruhi net worth maupun kinerja mereka, dengan melihat aktivitas ekspor dan impor perusahaan. Hampir sebagian besar dari sampel perusahaan (77 perusahaan atau hampir 60\% dari total sampel) melakukan kegiatan ekspor sebagai salah satu sumber penerimaan valas (Tabel 4 dan Tabel 5). Sebagian besar dari perusahaan (55 perusahaan) yang melakukan ekspor tersebut juga memiliki pengeluaran dalam valas dalam bentuk impor.

\begin{tabular}{|c|c|c|c|c|c|c|c|c|}
\hline \multicolumn{9}{|c|}{$\begin{array}{c}\text { Tabel } 4 . \\
\text { Jumlah Perusahaan Sampel yang melakukan } \\
\text { Kegiatan Ekspor dan Impor Perusahaan }\end{array}$} \\
\hline Perusahaan & & 2005 & 2006 & 2007 & 2008 & 2009 & 2010 & 2011 \\
\hline \multirow[t]{3}{*}{ Ekspor } & Impor & 70 & 63 & 69 & 69 & 52 & 55 & 50 \\
\hline & No Impor & 4 & 7 & 7 & 6 & 25 & 22 & 25 \\
\hline & Jumlah & 74 & 75 & 76 & 75 & 77 & 77 & 75 \\
\hline \multirow[t]{3}{*}{ No Ekspor } & Impor & 3 & 3 & 2 & 4 & 11 & 12 & 13 \\
\hline & No Impor & 51 & 50 & 50 & 49 & 40 & 39 & 40 \\
\hline & Jumlah & 54 & 53 & 52 & 53 & 51 & 51 & 53 \\
\hline
\end{tabular}

\begin{tabular}{|c|c|c|c|c|c|c|c|c|}
\hline \multicolumn{9}{|c|}{$\begin{array}{c}\text { Tabel } 5 . \\
\text { Persentasi (\%) Perusahaan Sampel yang } \\
\text { melakukan Kegiatan Ekspor dan Impor Perusahaan }\end{array}$} \\
\hline \multicolumn{2}{|c|}{$\%$ Total Perusahaan } & \multirow{2}{*}{\begin{tabular}{|r|}
2005 \\
55
\end{tabular}} & \multirow{2}{*}{$\begin{array}{r}2006 \\
53\end{array}$} & \multirow{2}{*}{\begin{tabular}{r|r}
2007 \\
54
\end{tabular}} & \multirow{2}{*}{\begin{tabular}{|r|}
2008 \\
54
\end{tabular} \mid} & \multirow{2}{*}{\begin{tabular}{r|}
2009 \\
41
\end{tabular}} & \multirow{2}{*}{$\begin{array}{r}2010 \\
43\end{array}$} & \multirow{2}{*}{$\begin{array}{r}2011 \\
39\end{array}$} \\
\hline Ekspor & Impor & & & & & & & \\
\hline & No Impor & 3 & 5 & 5 & 5 & 20 & 17 & 20 \\
\hline & Jumlah & 58 & 59 & 59 & 59 & 60 & 60 & 59 \\
\hline \multirow[t]{3}{*}{ No Ekspor } & Impor & 2 & 2 & 2 & 3 & 9 & 9 & 10 \\
\hline & No Impor & 40 & 39 & 39 & 38 & 31 & 30 & 31 \\
\hline & Jumlah & 42 & 41 & 41 & 41 & 40 & 40 & 41 \\
\hline
\end{tabular}

Namun dari perusahaan yang melakukan ekspor tersebut hanya 23 perusahaan atau 18\% dari total sampel yang melakukan transaksi hedging. Selain itu perusahaan yang tidak melakukan ekspor tetapi melakukan kegiatan impor semakin bertambah (Tabel 6). Dari perusahaan tersebut 
paling tinggi hanya 11 perusahaan atau 9\% dari total sampel yang melakukan transaksi derivatif. Kedua hal tersebut menunjukkan bahwa sampel perusahaan tersebut berpotensi mengalami risiko currency mismatch.

Dalam melakukan currency matching, perusahaan cenderung lebih mengandalkan sumber pendapatan valas lainnya, antara lain deposito valas. Selain itu, satu faktor penentu mengapa perusahaan tidak melakukan hedging adalah peningkatan rasio utang valas. Faktor lain yang ditengarai menjadi penyebab adalah karena tingginya biaya transaksi derivatif dalam rangka hedging.

Untuk memastikan hal ini, kami melakukan penulusuran lebih lanjut terhadap perilaku perusahaan dalam melakukan hedging, berdasarkan hasil Survei Manajemen Risiko yang dilakukan oleh Direktorat Internasional Bank Indonesia. Berdasarkan survey ini, salah satu penyebab perusahaan tidak melakukan hedging melalui transaksi derivatif karena besarnya biaya untuk melakukan transaksi tersebut serta persepsi stabilnya kondisi ekonomi domestik ke depan. Hal ini juga tercermin dari data sampel perusahaan yang menunjukkan bahwa dilihat dari total aset sampel perusahaan, sebagian besar perusahaan yang melakukan transaksi derivatif yaitu 43 perusahaan memiliki total aset di atas Rp1 Triliun (Grafik 16). Hal ini menunjukkan bahwa perusahaan yang melakukan transaksi hedging adalah perusahaan besar.

\begin{tabular}{|c|c|c|c|c|c|c|c|c|c|}
\hline \multicolumn{10}{|c|}{$\begin{array}{l}\text { Tabel } 6 . \\
\text { Perkembangan Perusahaan yang Melakukan Transaksi Derivatif }\end{array}$} \\
\hline \multicolumn{2}{|c|}{ Perusahaan } & \multirow{2}{*}{$\begin{array}{r}2005 \\
19\end{array}$} & \multirow{2}{*}{$\begin{array}{r}2006 \\
25\end{array}$} & \multirow{2}{*}{$\begin{array}{r}2007 \\
28\end{array}$} & \multirow{2}{*}{$\begin{array}{r}2008 \\
33\end{array}$} & \multirow{2}{*}{$\begin{array}{r}2009 \\
20\end{array}$} & \multirow{2}{*}{$\begin{array}{r}2010 \\
23\end{array}$} & \multirow{2}{*}{$\begin{array}{r}2011 \\
15\end{array}$} & \multirow{2}{*}{$\begin{array}{r}\text { Rata2 } \\
23\end{array}$} \\
\hline Ekspor & Derivatif & & & & & & & & \\
\hline & No Derivatif & 55 & 50 & 48 & 42 & 57 & 54 & 60 & 52 \\
\hline & Jumlah & 74 & 75 & 76 & 75 & 77 & 77 & 75 & 76 \\
\hline \multirow[t]{3}{*}{ No Ekspor } & Derivatif & 4 & 6 & 8 & 11 & 4 & 2 & 5 & 6 \\
\hline & No Derivatif & 50 & 47 & 44 & 42 & 47 & 49 & 48 & 47 \\
\hline & Jumlah & 54 & 53 & 52 & 53 & 51 & 51 & 53 & 52 \\
\hline \multicolumn{2}{|c|}{ Persentase } & 2005 & 2006 & 2007 & 2008 & 2009 & 2010 & 2011 & Rata2 \\
\hline \multirow[t]{3}{*}{ Ekspor } & Derivatif & 15 & 20 & 22 & 26 & 16 & 18 & 12 & 18 \\
\hline & No Derivatif & 43 & 39 & 38 & 33 & 45 & 42 & 47 & 41 \\
\hline & Jumlah & 58 & 59 & 59 & 59 & 60 & 60 & 59 & 59 \\
\hline \multirow[t]{3}{*}{ No Ekspor } & Derivatif & 3 & 5 & 6 & 9 & 3 & 2 & 4 & 4 \\
\hline & No Derivatif & 39 & 37 & 34 & 33 & 37 & 38 & 38 & 36 \\
\hline & Jumlah & 42 & 41 & 41 & 41 & 40 & 40 & 41 & 41 \\
\hline
\end{tabular}

Sumber: LapKeu Perusahaan, diolah 


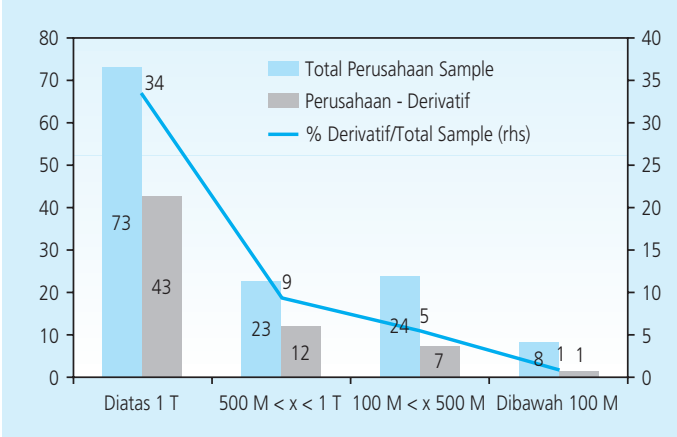

Sumber: LapKeu Perusahaan, diolah

Grafik 16.

Total Asset Perusahaan yang Melakukan Transaksi Derivatif

Survei ini dilakukan oleh Departemen Internasional BI pada bulan Juni 2011, dengan melibatkan 117 perusahaan pemilik ULN. Survei ini menunjukkan bahwa pangsa perusahaan yang melakukan transaksi derivatif untuk hedging masih terbatas yaitu hanya $21 \%$ dari sampel perusahaan (Grafik 17). Sedangkan instrumen utama yang digunakan untuk hedging adalah instrumen swap dan forward.

Jika dilihat secara fokus pada perusahaan non-keuangan, volume transaksi yang dilakukan terus mengalami peningkatan (Grafik 5, 6 dan 7). Sama seperti pelaku pasar lainnya, perusahaan non-keuangan lebih banyak melakukan transaksi valas dalam bentuk TTS yaitu sebesar $81 \%$ dari total transaksi. Sementara transaksi derivatif yang dilakukan oleh perusahaan non keuangan tersebut lebih banyak dalam bentuk forward (10\%), diikuti oleh swap (6\%) dan option (3\%).




Dalam survey tersebut juga dikemukakan pertimbangan perusahaan tidak melakukan hedging yaitu: (1) seluruhnya/sebagian produksi di ekspor atau penjualan di dalam negeri mengunakan standar valas (natural hedge), (2) perspektif terhadap perekonomian global dan domestik relatif stabil sehingga dipersepsikan risiko nilai tukar relatif rendah, (3) persepsi biaya hedging yang relatif mahal dibandingkan manfaat yang diperoleh, dan (4) memiliki anak perusahaan yang memiliki pendapatan valas.

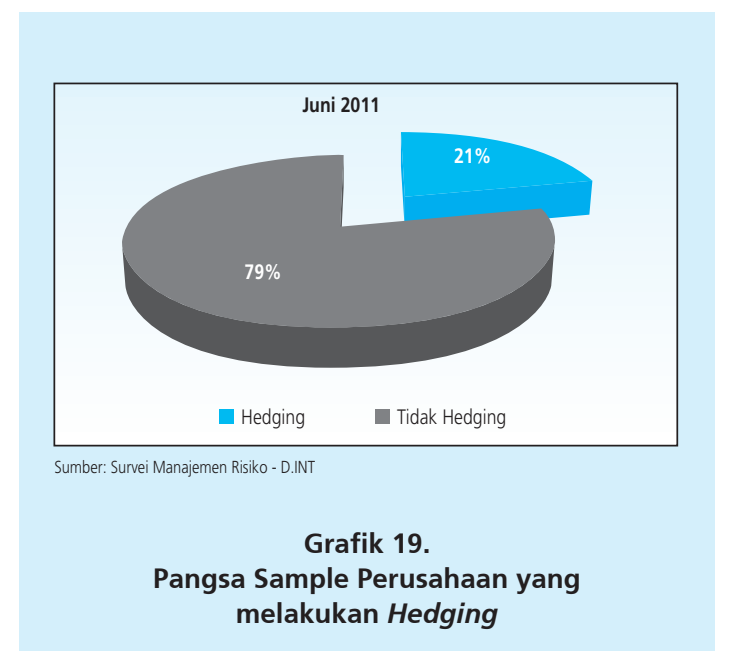

Dari survey tersebut diketahui pula upaya-upaya yang dilakukan perusahaan yang memiliki ULN tetapi tidak memiliki penerimaan valas dan tidak melakukan hedging, yaitu antara lain: (1) mencari sumber dana valas ke pasar secara bertahap dengan memperhatikan kondisi ekonomi, nilai tukar yang menguntungkan serta keuangan perusahaan (30\% dari sampel) (2) mencari sumber dana valas ke pasar pada saat akan melakukan pembayaran ULN ( $21 \%$ dari sampel), (3) meminjam dana valas ke perusahaan induk/afiliasi (19\% dari sampel), (4) menggunakan tabungan valas yang dimiliki perusahaan (12\% dari sampel), dan (5) melakukan debt to equity swap atau mengupayakan diversifikasi sumber-sumber penerimaan valas lainnya, atau belum melakukan tindakan karena kondisi yang belum stabil (12\% dari sampel).

Hasil estimasi, deskripsi data, dan survey di atas menunjukkan tidak signifikannya penggunaan aktivitas hedging terhadap kinerja perusahaan. Perusahaan lebih menggunakan upaya lain selain hedging dalam memitigasi risiko nilai tukar sebagai bagian dari upaya currency matching yaitu diantaranya adalah meminjam dari perusahaan induk atau melakukan debt to equity swap. 


\section{KESIMPULAN}

Paper ini membahas sejauhmana peranan hedging melalui transaksi derivatif (currency hedging) bagi perusahaan non keuangan yang telah go public untuk melakukan lindung nilai atas ULN yang dimiliki dengan pendekatan balance sheet effect. Hasil pengujian empiris dengan menggunakan metode data panel perusahaan non keuangan dari 2005 - 2011 mengkonfirmasikan bahwa peranan currency hedging dalam rangka lindung nilai kewajiban ULN masih terbatas. Tidak berperannya currency hedging terhadap kinerja perusahaan mengindikasikan bahwa perusahaan belum memiliki dorongan yang kuat untuk melakukan currency hedging. Perusahaan menggunakan upaya lain selain hedging dalam memitigasi risiko nilai tukar yaitu diantaranya dengan melakukan pinjaman dari perusahaan induk atau melakukan debt-to-equity swap.

Sementara itu dengan menggunakan data LHBU, hasil pemetaan di pasar valas, menunjukkan bahwa pasar derivatif di Indonesia masih belum berkembang baik ditinjau dari sisi instrumen maupun pelaku pasar. Pasar valas domestik masih didominasi oleh transaksi tunai berupa TTS sementara transaksi derivatif hanya berperan sekitar 30\% dari total transaksi. Selain itu peran perusahaan di transaksi derivatif hanya relatif kecil yaitu sekitar $7 \%$ dari total transaksi di pasar valas. Baik transaksi TTS maupun derivatif masih didominasi oleh sektor perbankan.

Berdasarkan Survei Manajemen Risiko yang telah dilakukan oleh Departemen Internasional Bank Indonesia, perusahaan tidak melakukan hedging akibat dari beberapa faktor yaitu perusahaan tersebut telah melakukan natural hedging, persepsi perusahaan atas rendahnya risiko nilai tukar, masih relatif mahalnya biaya hedging serta perusahaan telah memiliki anak perusahaan yang berpendapatan valas. Perusahaan yang tidak melakukan hedging memiliki beberapa cara untuk memenuhi kewajiban luar negeri antara lain mencari sumber valas secara bertahap dengan memperhatikan kondisi ekonomi dan nilai tukar yang menguntungkan, serta melakukan pinjaman kepada induk atau afiliasinya.

Berdasarkan hasil pengujian di atas dan mengingat potensi risiko depresiasi nilai tukar yang tajam dapat terjadi tidak terduga, Bank Indonesia perlu terus mengembangkan kebijakan dan peraturan yang bertujuan untuk memperdalam pasar valas maupun pasar derivatif domestik (market deepening). Beberapa kebijakan tersebut diantaranya adalah kebijakan dengan menyediakan instrument currency hedging yang lebih komprehensif dan market friendly kepada bank maupun perusahaan. Identifikasi mengenai jenis instrumen hedging yang tepat dapat dikomunikasikan kepada perusahaan-perusahaan besar yang memiliki utang valas beserta leading bank. Selain itu, kebijakan berikutnya adalah Bank Indonesia beserta pihak terkait perlu melakukan sosialisasi kepada perusahaan yang memiliki ULN mengenai manfaat transaksi currency hedging untuk melindungi kondisi keuangannya apabila terjadi depresiasi nilai tukar yang tidak terduga. Sosialisasi tersebut dapat dilakukan bekerja sama dengan Pemerintah melalui departemen terkait maupun pihak swasta melalui asosiasi terkait. 


\section{DAFTAR PUSTAKA}

Aghion, Phillipe, Philippe Bacchetta dan Abhijit Banerjee. (2001). Currency Crises and Monetary Policy in an Economy with Credit Constraint. European Economic Review 45 (2001) 1121-1150.

Allayanis, G, Gregory W. Brown dan Leora F. Klaper. (2001). Exchange Rate Risk Management: Evidence From East Asia. Working Paper No. 01-09, Darden Graduate School of Business Administration, University of Virginia.

Borsum, Øystein G. dan Bernt Arne Ødegaard. (2005). Currency Hedging in Norwegian NonFinancial Firms. Economic Bulletin 05 Q3.

Cespedes, Luis Felipe, Roberto Chang dan Andrés Velasco. (2004). Balance Sheets and Exchange Rate Policy. The American Economic Review, Vol. 94, No. 4, pp. 1183-1193. American Economic Association.

Chen, Dar-Hasin, Hwey-Yun Yau, Chin-Lin Chuang, dan Po-Cheng Kuo. (2011). Trading Behaviors Among Major Investors in The United States Dollar (USD) Currency Futures Markets: Evidence From South Korea. African Journal of Business Management, Vol.5 (28), pp. 11295-11308.

Cowan, Kevin, Erwin Hansen, Luis Oscar Herrera. (2005). Currency Mismatches, BalanceSheet Effects and Hedging in Chilean Non-Financial Corporations. Working Paper \#521, Inter-American Development Bank, Research Department, Departamento de Investigación, Central Bank of Chile.

Kamil, Herman. (2009). How Do Exchange Rate Regimes Affect Firms' Incentives to Hedge Currency Risk in Emerging Markets?, Washington DC: International Monetary Fund.

Kedia, Simi, Abon Mozumdar. (2003). Foreign Currency-Denominated Debt: An Empirical Examination. Journal of Business, 2003, Vol. 76, No. 4, The University of Chicago.

Laporan Survei Manajemen Risiko Semester II. (2011). Departemen Internasional, Bank Indonesia.

Sharma, Somnath. (2011). An Empirical Analysis of the Relationship Between Currency Futures and Exchange Rates Volatility in India. RBI Working Paper Series, WPS (DEPR): 1/2011, Department of Economic and Policy Research, Reserve Bank of India.

Sahminan. (2006). Adjustments of the Non-Financial Sector to the Rise in Exchange Rate Volatility and Their Policy Implications in Indonesia. Working Paper No. WP/14/2006, Biro Riset Ekonomi, Direktorat Riset Ekonomi dan Kebijakan Moneter, Bank Indonesia. 